\title{
Modeling of the Distribution of Radon and Its Decay in a Traditional Hammam: Dose to Adult Members of the Public
}

\author{
Rabi Rabi ${ }^{1}{ }^{*}$, Lhoucine Oufni ${ }^{1}$, El-Houcine Youssoufi ${ }^{1}$, Khamiss Cheikh ${ }^{2}$, Hamza Badry ${ }^{1}$, \\ Youssef Errami ${ }^{2}$ \\ ${ }^{1}$ Department of Physics (LPM), Faculty of Sciences and Techniques, Sultan Moulay Sliman University, Beni-Mellal, Morocco \\ ${ }^{2}$ Department of Physics (LEIE), Faculty of Sciences, Chouaib Doukkali University, El Jadida, Morocco
}

Email address:

rabiismcm@gmail.com (R. Rabi)

${ }^{*}$ Corresponding author

\section{To cite this article:}

Rabi Rabi, Lhoucine Oufni, El-Houcine Youssoufi, Khamiss Cheikh, Hamza Badry, Youssef Errami. Modeling of the Distribution of Radon and Its Decay in a Traditional Hammam: Dose to Adult Members of the Public. American Journal of Environmental Protection.

Vol. 10, No. 1, 2021, pp. 12-21. doi: 10.11648/j.ajep.20211001.12

Received: February 23, 2021; Accepted: March 8, 2021; Published: March 12, 2021

\begin{abstract}
Radon and its descendants are the main causes of lung cancer in non-smokers. Therefore, the study of the behavior of radon and its descendants in indoor air is of the highest importance, in ordre to limit the risk of radiation dose due to inhalation of indoor air by members of the public. This article focuses to study the effect of meteorological parameters on the concentration and distribution of radon and its descendants inside a traditional Hammam by using CFD simulation. The results of modeling are qualitative and show that the concentration and distribution of radon and its descendants decrease when the ventilation rate increases, as well as, as the temperature increases; however, it increases with the increase relative humidity. Moreover, the committed equivalent doses due to ${ }^{218} \mathrm{Po}$ and ${ }^{214} \mathrm{Po}$ radon short-lived progeny were evaluated in different tissues of the respiratory tract of the members of the public from the inhalation of air inside the traditional Hammam. The influence of the activity of ${ }^{218} \mathrm{Po}$ and ${ }^{214} \mathrm{Po}$ and mass of the tissue on the committed equivalent doses per hour of exposure was investigated. The annual effective dose due to radon short-lived progeny from the inhalation of air inside the traditional Hammam by the members of the public was investigated.
\end{abstract}

Keywords: Radon, Traditional Hammam, Computational Fluid Dynamics (CFD), Annual Equivalent Doses

\section{Introduction}

Radon is emitted by radium in soil, groundwater, and building materials. It can penetrate into the interior air where it accumulates. It is well known that inhalation of radon and its decay products contribute a significant share (over 50\%) of the natural radiation dose to humans. [1]. Therefore, the estimation of the behavior of radon and its decay into the interior air is very important to evaluate the radiation dose received from inhalation of radon and its decay by members of the public.

More recently, CFD (Computational Fluid Dynamics) simulation has taken on a distinct place in the study of the behavior of radon in indoor air. Many researchers have predicted the behavior and distribution of radon in buildings, apartments, offices, and schools, using CFD simulations [2-
9]. Despite the importance of these studies, the evaluation of the influence of meteorological parameters on the behavior of radon and its descendants in indoor air has not been fully investigated using CFDs.

In this article, we analyze the influence of meteorological parameters on the behavior of radon inside a traditional Hammam Moroccan. The study will focus essentially on the effects of ventilation, temperature, and relative humidity on the concentration and distribution of radon and its descendants inside a traditional Hammam. Finally, we evaluate the annual effective dose due to the inhalation of ${ }^{218} \mathrm{Po}$ and ${ }^{214} \mathrm{Po}$ inside the traditional Hammam by members of the public. 


\section{The Hammam Plan Geometry}

A traditional Hammam Moroccan is a place of relaxation and care generally consists of three rooms whose temperature varies; so that we find a coldroom when entering, another warmroom in the middle, then the hotroom (Figure 1). These rooms summarize the three main steps of the bath process.

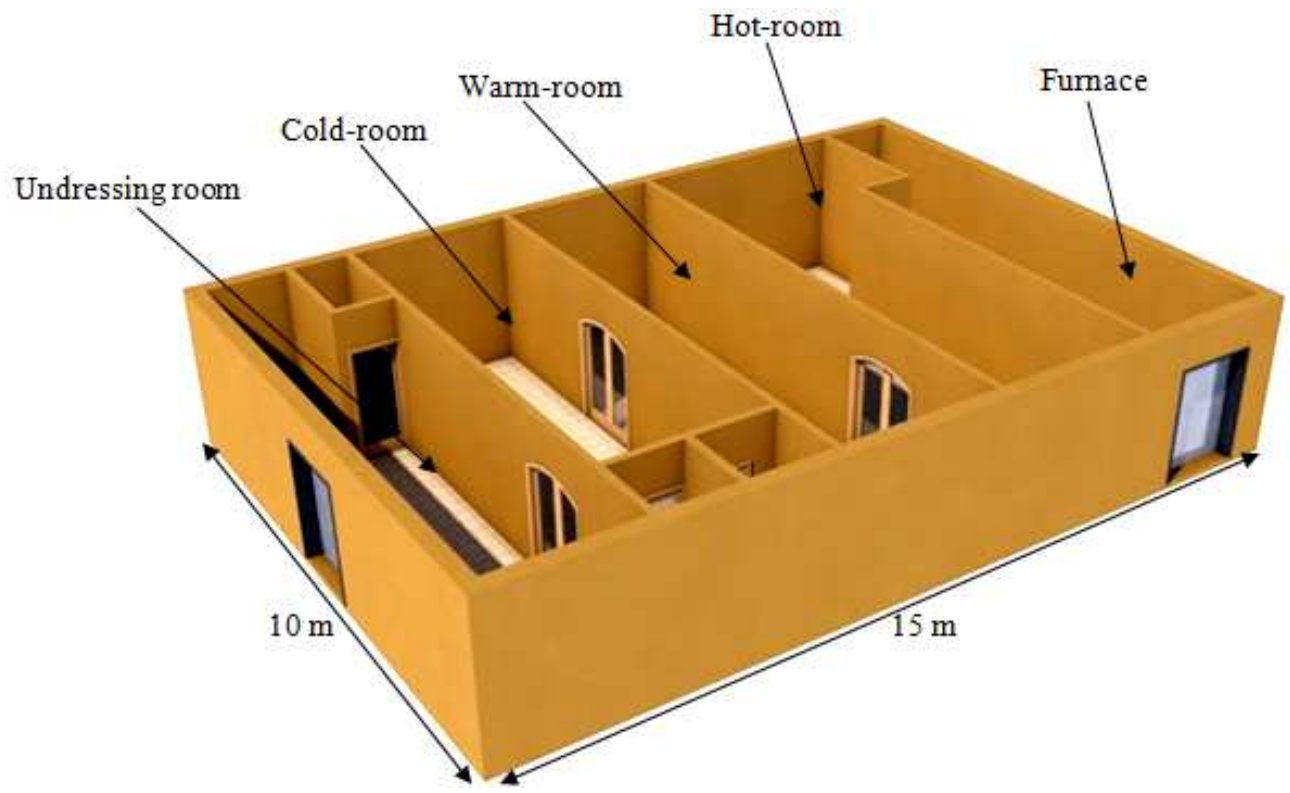

Figure 1. Geometry of the hammam traditional.

\section{Governing Equations Used}

In this study we applied the Navier-Stokes equations in the laminar regime, written as follows [7]: The conservation of mass equation:

$$
\frac{\partial\left(\rho \mathrm{U}_{\mathrm{i}}\right)}{\partial \mathrm{X}_{\mathrm{i}}}=0
$$

The momentum equation:

$$
\frac{\partial\left(\rho \mathrm{U}_{\mathrm{i}}\right)}{\partial \mathrm{t}}+\frac{\partial\left(\rho \mathrm{U}_{\mathrm{i}} \mathrm{U}_{\mathrm{j}}\right)}{\partial \mathrm{X}_{\mathrm{i}}}=-\frac{\partial \mathrm{P}}{\partial \mathrm{X}_{\mathrm{i}}}+\frac{\partial}{\partial \mathrm{X}_{\mathrm{i}}}\left[\mu\left(\frac{\partial \mathrm{U}_{\mathrm{i}}}{\partial \mathrm{X}_{\mathrm{i}}}+\frac{\partial \mathrm{U}_{\mathrm{j}}}{\partial \mathrm{X}_{\mathrm{i}}}\right)\right]+\rho \mathrm{g}
$$

The energy conservation equation:

$$
\frac{\partial \mathrm{T}}{\partial \mathrm{t}}+\frac{\partial\left(\mathrm{U}_{\mathrm{i}} \mathrm{T}\right)}{\partial \mathrm{X}_{\mathrm{i}}}=\alpha \frac{\partial^{2} \mathrm{~T}}{\partial \mathrm{X}_{\mathrm{i}}{ }^{2}}
$$

The equation of dispersion for radon and its descendants:

$$
\frac{\partial C_{j}}{\partial t}+\frac{\partial\left(U_{i} C_{j}\right)}{\partial X_{i}}=D \frac{\partial^{2} C_{j}}{\partial X_{i}^{2}}-\lambda_{j} C_{j}
$$

where: $\mathrm{u}, \mathrm{v}$ and $\mathrm{w}$ are the velocity components, $\mathrm{x}, \mathrm{y}$ and $\mathrm{z}$ are the Cartesian coordinates used, $\mathrm{T}$ is the temperature, $\mathrm{p}$ is the pressure, $\alpha$ is the thermal diffusivity, $C_{j}$ is the concentration of radon decay $\left(j=0,1,2,3\right.$ and 4 for ${ }^{222} \mathrm{Rn}$,
${ }^{218} \mathrm{Po},{ }^{214} \mathrm{~Pb},{ }^{214} \mathrm{Bi}$ and ${ }^{214} \mathrm{Po}$ ), D is the diffusion coefficient, and $\lambda_{j}$ is the decay constant of radon decay.

\section{Resolution Method}

The Navier-Stockes equations described above have been discretized by the Finite Volumes Method. The mesh employed is structured quadratic. The advection terms are discretized using the QUICK scheme. Diffusion terms are processed using the second-order scheme. The SIMPLER algorithm was used for the pressure-velocity coupling.

\section{Boundary Conditions and Input Data}

The floor in the hotroom is considered a source of heat and vapor, and all walls and ceilings are modeled adiabatic. The heat is produced by water vapor which gives a very humid environment (with a humidity rate of up to $100 \%$ ), whose temperature varies between $20^{\circ} \mathrm{C}$ and $50^{\circ} \mathrm{C}$. The details of the boundary conditions are presented in the Table 1 . The boundary condition of radon decay on the walls is simplified by $\left(\partial \mathrm{C}_{\mathrm{j}}\right) / \partial \mathrm{n}=0$, where $\mathrm{n}$ is the direction normal to the wall [6].

Table 1. Properties of the fluids and solids [11].

\begin{tabular}{llll}
\hline Material & Density $\left(\mathbf{k g ~ m}^{-\mathbf{3}}\right)$ & Heat capacity $\left(\mathbf{j} \mathbf{~ k g}^{\mathbf{- 1}} \mathbf{k}^{\mathbf{- 1}}\right)$ & ${\text { Thermal conductivity }\left(\mathbf{W} \mathbf{~ m}^{\mathbf{- 1}} \mathbf{k}^{\mathbf{- 1}}\right)}$ \\
\hline Air & 1.225 & 1006.43 & 0.024 \\
Water vapor & 0.554 & 2.014 & 0.026 \\
Radon & 9.73 & 93.55 & 0.0036 \\
Dense concrete & 2100 & 840 & 0.8 \\
Main door and Internal Doors & 720 & 1250 & 0.16 \\
\hline
\end{tabular}




\section{The Equilibrium Factor}

The equilibrium factor between radon and its descendants is a dimensionless parameter and is defined as follows [10]:

$$
F=\frac{0.105 \cdot C_{1}+0.516 \cdot C_{2}+0.379 . C_{3}}{C_{0}}
$$

where $C_{j}$ is the concentrations of radon decay in the house $\left(\mathrm{Bq} \mathrm{m} \mathrm{m}^{-3}\right)$, respectively $\left(\mathrm{j}=0,1,2\right.$ and 3 for ${ }^{222} \mathrm{Rn},{ }^{218} \mathrm{Po},{ }^{214} \mathrm{~Pb}$ and $\left.{ }^{214} \mathrm{Bi}\right)$.

\section{Determination of Annual Committed Equivalent Doses}

According to the ICRP Publication 66 [12] (Figure 2), the human respiratory tract is divided into two major regions:
1) The thoracic region: is divided into four sub-regions (alveolar interstitium AI, bronchioles bb, bronchi BB and lymphatics $\mathrm{LN}_{\mathrm{TH}}$ ).

2) The extrathoracic region: contains four compartments named $\mathrm{ET}_{2}, \mathrm{ET}_{\text {seq }}, \mathrm{LN}_{\mathrm{ET}}$ and $\mathrm{ET}_{1}$.

The alpha-activity of radon decay in compartment $i$ of the respiratory tract am given by the following. [12]:

$$
\frac{d A_{c}^{i}(j)}{d t}=F_{d}(i) I_{0}(j)+\sum_{n} \lambda_{n, i} A_{c}^{n}(j)-\left(\sum_{n} \lambda_{i, n}+\lambda_{j}\right) A_{c}^{i}(j)
$$

where $F_{d}(i)$ is the fractional deposition in the compartment $i$ of the respiratory tract (ICRP), $I_{0}(j)$ is the average breathing rate. $C(j)$ is the concentration of the radon decay product inside the Hammam, $\lambda_{n, i}$ is the clearance rate from region $n$ to region i due to particle transport (ICRP).

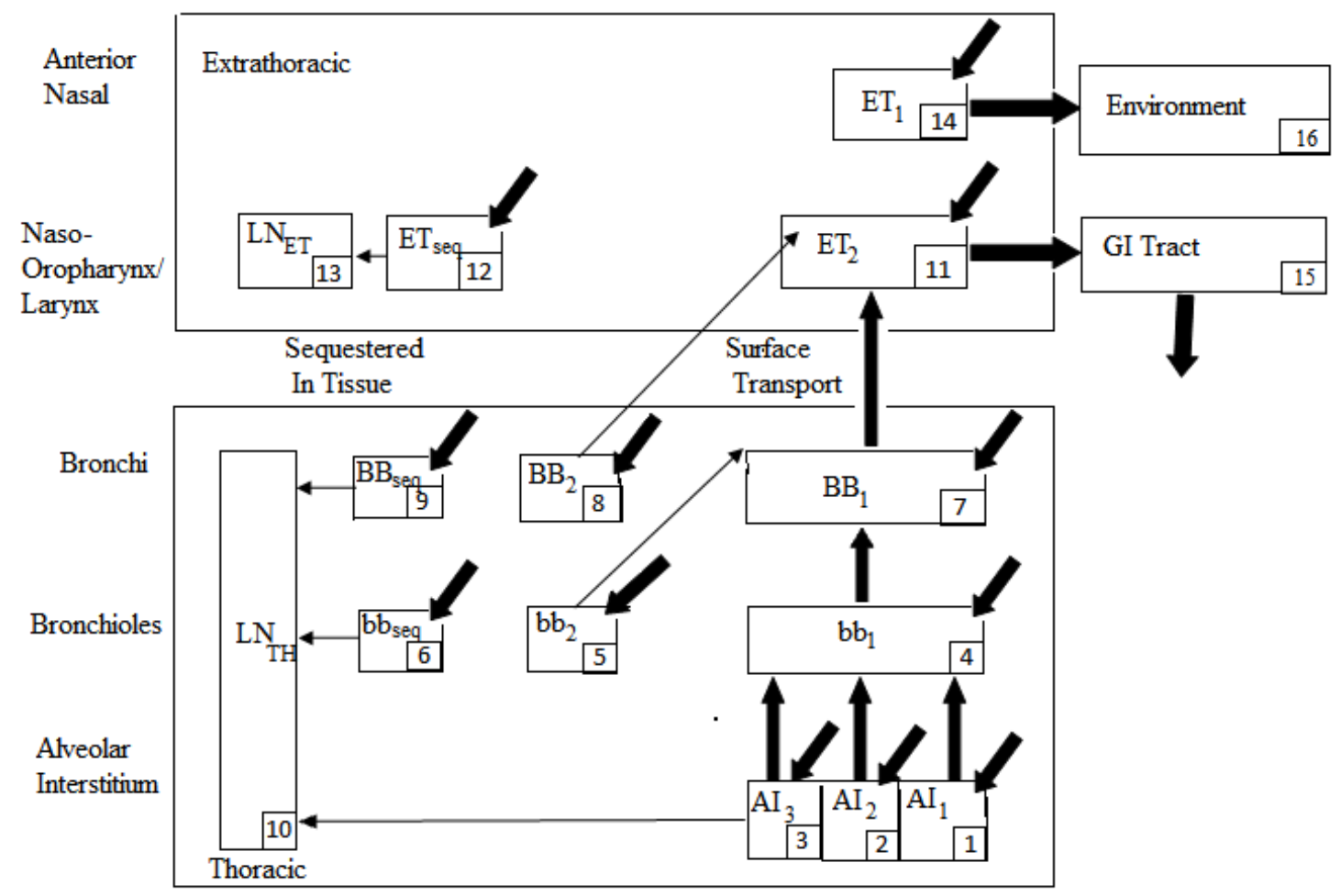

Figure 2. Compartment model showing particle transport from each region.

The alpha-equivalent dose rate $\left(\mathrm{Sv} \mathrm{s}^{-1}\right)$ in a tissue $\mathrm{T}$ of the respiratory tract of an individual due to the inhalation of the radon decay given by:

$$
\dot{\mathrm{H}}_{\mathrm{T}}(\mathrm{j})=\mathrm{A}_{\mathrm{c}}^{\mathrm{T}}(\mathrm{j})(\mathrm{t}) \cdot \mathrm{Q} \cdot \mathrm{k} \cdot \frac{\mathrm{K}_{\mathrm{j}} \mathrm{R}_{\mathrm{j}} \mathrm{S}_{\mathrm{j}}}{\mathrm{m}_{\mathrm{T}}}
$$

where $A^{T}(j)(t)(B q)$ is the alpha-activity of radon decay product in the tissue $\mathrm{T}$ of the respiratory tract, $\mathrm{Q}$ is the quality factor, which is equal to 20 for $\alpha$-particles [12]. $\mathrm{m}_{\mathrm{T}}$ is the mass of the target tissue $T, K_{j}$ is the branching ratio, $R_{j}$ is the range of the $\alpha$-particle emitted by radon decay product, $\mathrm{S}_{\mathrm{j}}$ is the stopping power of the tissue $\mathrm{T}$ for the emitted $\alpha$-particle and $k\left(1.6 \times 10^{-10}\right)$ is a conversion factor. $R_{j}$ and $S_{j}$ were calculated by using the SRIM program [12].
The equivalent dose in the tissue $\mathrm{T}$ of the respiratory tract for radon decay is given by the following:

$$
\mathrm{H}_{\mathrm{T}}(\mathrm{j})=\int_{0}^{\mathrm{t}_{\mathrm{e}}^{\prime}} \dot{\mathrm{H}}_{\mathrm{T}}(\mathrm{j})(\mathrm{t}) \mathrm{dt}
$$

where $t_{e}^{\prime}$ is the exposure time of the tissue $T$ and $\dot{H}_{T}(j)$ is the alpha-equivalent dose rate $\left(\mathrm{Sv} \mathrm{s}^{-1}\right)$ in a tissue $\mathrm{T}$.

Regional doses, weighted with factors assigned for the partition of radiation detriment, are summed to give a value of committed equivalent dose for the thoracic $\mathrm{H}_{\mathrm{TH}}(\mathrm{j})$ and extrathoracic $\mathrm{H}_{\mathrm{ET}}(\mathrm{j})$ regions. According to the ICRP 66 [12], we have the following equations:

$$
\mathrm{H}_{\mathrm{TH}}(\mathrm{j})=\mathrm{A}_{\mathrm{BB}} \mathrm{H}_{\mathrm{BB}}(\mathrm{j})+\mathrm{A}_{\mathrm{bb}} \mathrm{H}_{\mathrm{bb}}(\mathrm{j})+\mathrm{A}_{\mathrm{AI}} \mathrm{H}_{\mathrm{AI}}(\mathrm{j})
$$


and

$$
H_{E T}(j)=A_{E T 1} H_{E T 1}(j)+A_{E T 2} H_{E T 2}(j)
$$

where $\mathrm{H}_{\mathrm{BB}}(\mathrm{j}), \mathrm{H}_{\mathrm{bb}}(\mathrm{j})$ and $\mathrm{H}_{\mathrm{AI}}(\mathrm{j})$ are the equivalent doses in the $\mathrm{BB}, \mathrm{bb}$ and $\mathrm{AI}$ tissues of the thoracic region, respectively; $\mathrm{H}_{\mathrm{ET} 1}(\mathrm{j})$ and $\mathrm{H}_{\mathrm{ET} 2}(\mathrm{j})$ are the equivalent doses in the $\mathrm{ET}_{1}$ and $\mathrm{ET}_{2}$ tissues of the extrathoracic region, respectively; $\mathrm{A}_{\mathrm{BB}}=$ $0.333, \mathrm{~A}_{\mathrm{bb}}=0.333$ and $\mathrm{A}_{\mathrm{AI}}=0.333$ are the weighting

$$
\mathrm{E}=0.12\left[\mathrm{H}_{\mathrm{TH}}\left({ }^{218} \mathrm{Po}\right)+\mathrm{H}_{\mathrm{TH}}\left({ }^{214} \mathrm{Po}\right)\right]+0.025\left[\mathrm{H}_{\mathrm{ET}}\left({ }^{218} \mathrm{Po}\right)+\mathrm{H}_{\mathrm{ET}}\left({ }^{214} \mathrm{Po}\right)\right]
$$

The annual effective dose ( $\mathrm{mSv} \mathrm{y}^{-1} \mathrm{~h}^{-1}$ of exposure) due to the radon decay to the members of the public was also estimated according to the following formula [1]:

$$
\mathrm{E}=\mathrm{A}_{\mathrm{c}}\left({ }^{222} \mathrm{Rn}\right) \times \mathrm{F} \times \mathrm{t} \times \mathrm{D}
$$

factors for the partition of radiation detriment for the $\mathrm{BB}, \mathrm{bb}$ and AI tissues of the thoracic region, respectively, and $\mathrm{A}_{\mathrm{ET} 1}=0.001$ and $\mathrm{A}_{\mathrm{ET} 2}=1$ are the weighting factors for the partition of radiation detriment for the $\mathrm{ET}_{1}$ and $\mathrm{ET}_{2}$ extrathoracic regions [12].

The annual effective dose ( $\mathrm{mSv} \mathrm{y}^{-1} \mathrm{~h}^{-1}$ exposure) due to radon decay products inside the Hammam was evaluated by using the following equation:

Table 2. Result of grid independence examination.

\begin{tabular}{llll}
\hline Number of grids & Average radon concentration $\left(\mathbf{B q ~ m}^{-\mathbf{3}}\right)$ & Average temperature $(\mathbf{K})$ & Average relative humidity $(\%)$ \\
\hline $2,026,990$ & 292.41 & 297.99 & 40.52 \\
$2,902,409$ & 291.25 & 297.25 & 40.52 \\
$3,777,828$ & 290.41 & 297.09 & 40.52 \\
\hline
\end{tabular}

\section{Results and Discussion}

\subsection{Effect of Mesh on the Numerical Solution}

The sensitivity of the results compared to the mesh was checked before proceeding to the calculations. To do this, we took into account three different meshes $(2,026,990$, $2,902,409$ and $3,777,828$ cells). The results obtained after the convergence for each mesh are shown in Table 2. It is clear that the variation in the average radon concentration between mesh sizes 2,026,990 and 3,777,828 is negligible.

\subsection{Effect of Ventilation}

In order to study the effect of ventilation on the concentration and distribution of radon and its descendants inside the Hammam, we considered two cases: In the first, we considered the door of the coldroom closed and left the interior doors open (most dominant situation), and in the second we considered all the doors are open (least dominant situation).

Figures 3 and 4 show the iso-concentrations of radon in the Hammam for the two cases studied respectively, plotted in the horizontal median plane $(\mathrm{Y}=1.5 \mathrm{~m})$. We observe that the radon concentration decreases by increasing ventilation. This decrease is caused by the introduction of fresh air.

In Tables 3 and 4, we present the average concentrations of radon and its descendants as well as the equilibrium factor for different cases of ventilation. We note that the ventilation sufficiently dilutes the concentration of radon and its descendants inside the Hammam. We also note that the hotroom is more polluted than the other rooms (coldroom, warmroom). This is due to the fact that the ventilation rate decreases when as we move away from the entrance to the Hammam.

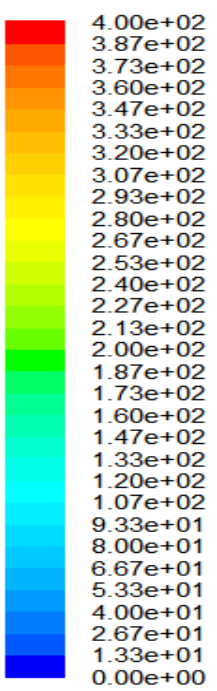

Figure 3. Contours of radon concentration $\left(B \mathrm{~m} \mathrm{~m}^{-3}\right)$ in closed Hammam at plane $(Y=1.50 \mathrm{~m})$. 
Figure 4. Contours of radon concentration $\left(B q \mathrm{~m}^{-3}\right)$ in open Hammam at plane $(Y=1.50 \mathrm{~m})$.

Table 3. Average indoor radon concentration $\left(B \mathrm{~m}^{-3}\right)$ in Closed hammam.

\begin{tabular}{llllll}
\hline Space & ${ }^{222} \mathbf{R n}$ & ${ }^{218} \mathbf{P o}$ & ${ }^{214} \mathbf{P b}$ & ${ }^{214} \mathbf{B i}$ & $\mathbf{F}$ \\
\hline Coldroom & 280.23 & 195.73 & 119.41 & 104.61 & 0.43 \\
Warmroom & 287.32 & 200.62 & 122.40 & 107.23 & 0.43 \\
Hotroom & 307.14 & 214.70 & 130.99 & 114.75 & 0.73 \\
\hline
\end{tabular}

Figures 5 and 6 illustrate the isoconcentrations of ${ }^{218} \mathrm{Po}$ and the distribution of the equilibrium factor, plotted on the horizontal median plane $(\mathrm{Y}=1.5 \mathrm{~m})$. We notice that the ${ }^{218} \mathrm{Po}$ has a distribution similar to that of radon, similar results have been found by other authors $[13,14]$. We also find that the equilibrium factor is more important in the hotroom. This is because the humidity level is too high in this room (Figure 7).

Table 4. Average indoor radon concentration $\left(\mathrm{Bq} \mathrm{m}^{-3}\right)$ in Opened hammam.

\begin{tabular}{llllll}
\hline Space & ${ }^{\mathbf{2 2}} \mathbf{R n}$ & ${ }^{2 \mathbf{1 8}} \mathbf{P o}$ & ${ }^{\mathbf{2 1 4}} \mathbf{P b}$ & ${ }^{\mathbf{2 1 4}} \mathbf{B i}$ & \\
\hline Coldroom & 260.56 & 181.10 & 105.34 & 88.91 & \\
Warmroom & 274.95 & 190.38 & 110.74 & 93.46 & 0.41 \\
Hotroom & 291.62 & 202.19 & 117.61 & 99.26 \\
\hline
\end{tabular}

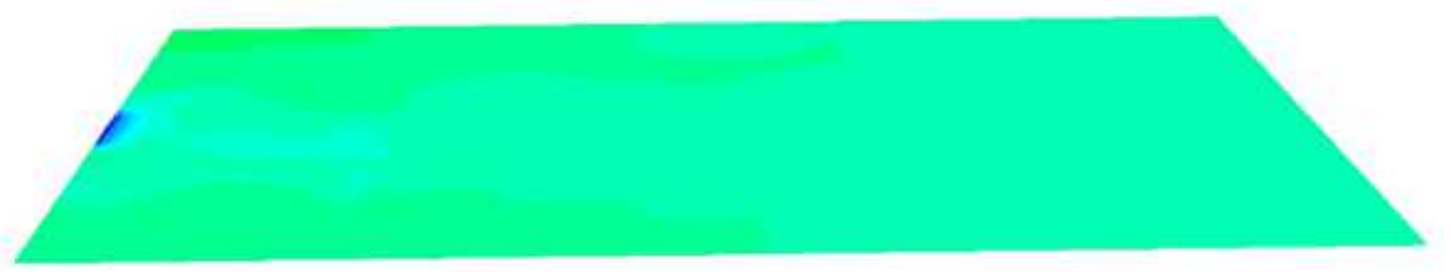

Figure 5. Contours of ${ }^{218} \mathrm{Po}\left(\mathrm{Bq} \mathrm{\textrm {m } ^ { - 3 }}\right)$ in open Hammam at plane $(Y=1.50 \mathrm{~m})$. 


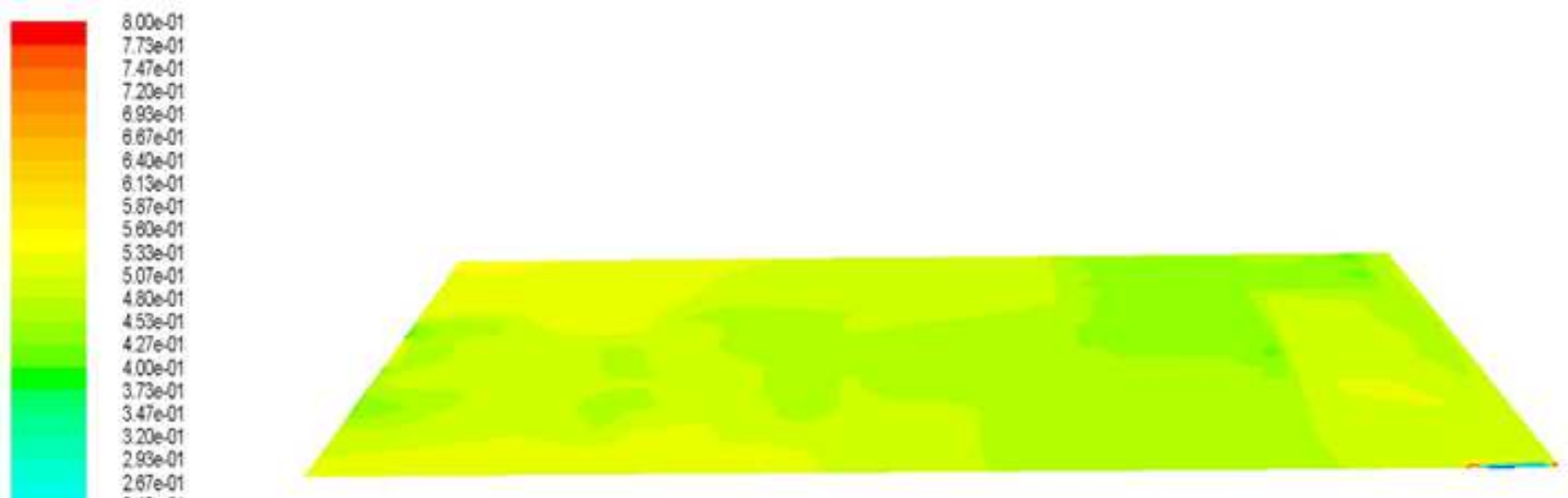

Figure 6. Contours of equilibrium factor in the Hammam at plane $(Y=1.50 \mathrm{~m})$.
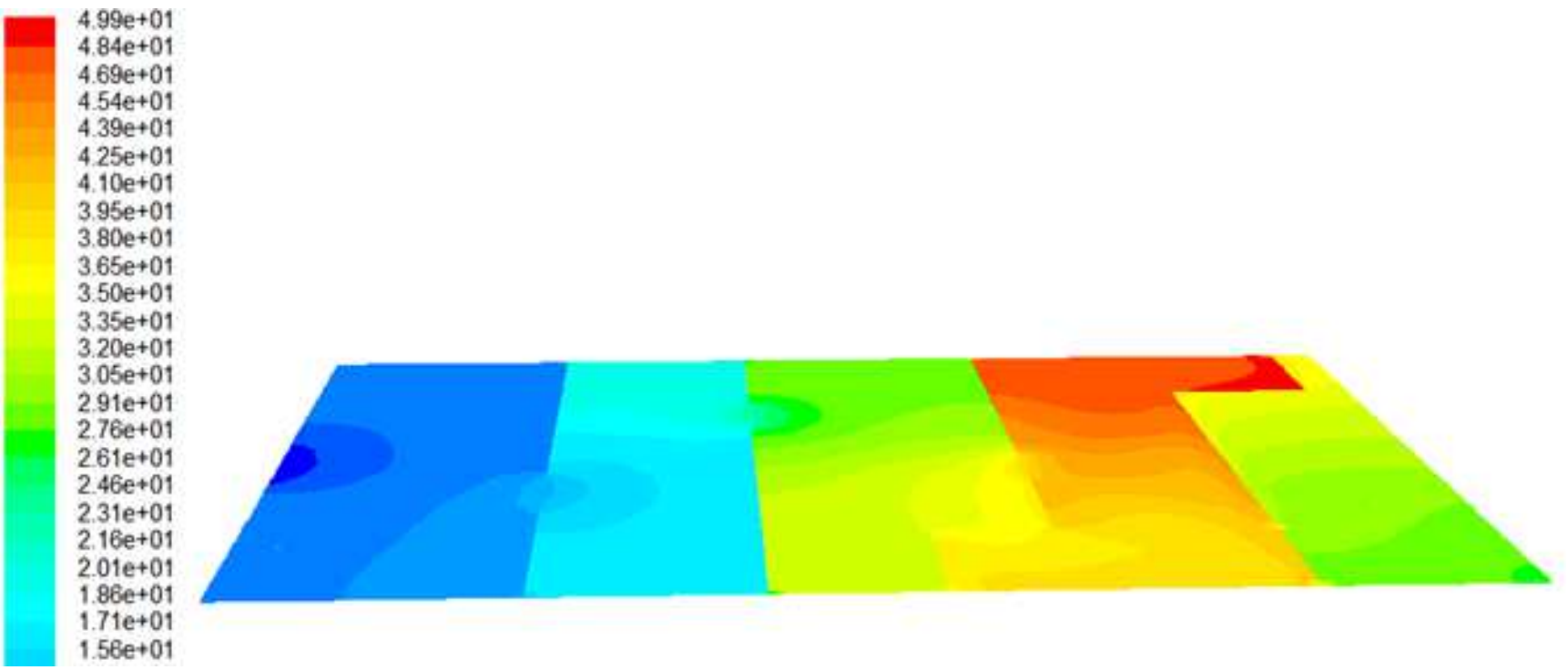

Figure 7. Contours of relative humidity at plane $(Y=1.50 \mathrm{~m})$.

\subsection{Effect of Temperature}

The influence of temperature on the concentration and distribution of radon and its descendants inside the Hammam studied. We have considered five temperatures the values are $15,17,20,22$, and $25^{\circ} \mathrm{C}$, with a relative humidity is around
$40 \%$ and the interior doors are left open.

Table 5 represent the average values of the concentration of radon and its descendants inside the hotroom as a function of temperature. We observe that the concentration of radon and its descendants decreases considerably with temperature.

Table 5. Average radon concentration $\left(\mathrm{Bq} \mathrm{m}^{-3}\right)$ in hotroom for various temperature with $\mathrm{RH}=40 \%$.

\begin{tabular}{lllll}
\hline Temperature $\left({ }^{\circ} \mathbf{C}\right)$ & ${ }^{222} \mathbf{R n}$ & ${ }^{218} \mathbf{P o}$ & ${ }^{214} \mathbf{P b}$ & ${ }^{\mathbf{2 1 4}} \mathbf{B i}$ \\
\hline 25 & 318.88 & 200.95 & 108.44 & 94.35 \\
30 & 307.14 & 139.99 & 104.68 & 91.09 \\
35 & 287.84 & 181.36 & 97.86 & 85.15 \\
40 & 281.61 & 177.56 & 95.82 & 0.35 \\
45 & 280.83 & 176.93 & 95.48 & 0.35 \\
50 & 280.30 & 176.30 & 95.14 & 0.35 \\
\hline
\end{tabular}




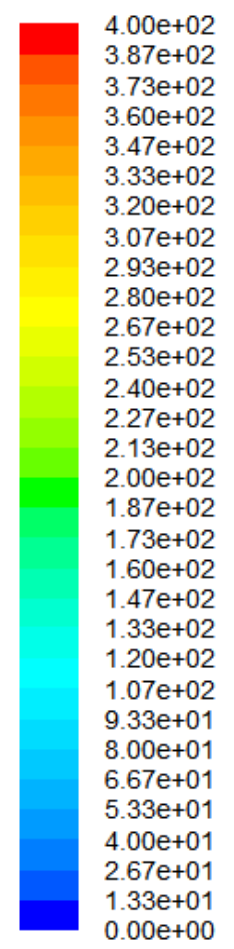

Figure 8. Contours of radon concentration in the Hammam for $T=35^{\circ} \mathrm{C}$.

To have a clear idea of the effect of temperatures on the distribution of radon inside the Hammam, we present the isoconcentrations of radon for two temperatures $35^{\circ} \mathrm{C}$ and $45^{\circ} \mathrm{C}$ respectively (Figures 8 and 9). By comparing these figures, we see that the increase in temperature has a slight influence on the radon distribution.

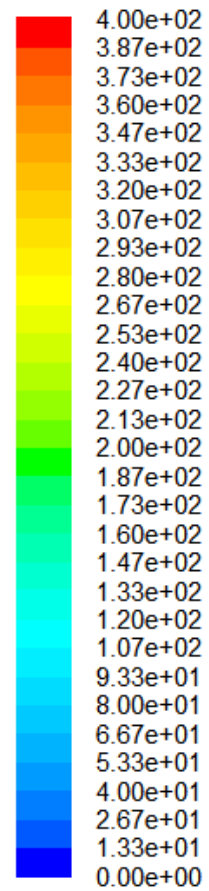

Figure 9. Contours of radon concentration in the Hammam for $T=45^{\circ} \mathrm{C}$.

\subsection{Effect of Relative Humidity}

In order to study the effect of relative humidity on the concentration and distribution of radon and its descendants inside the Hammam, we considered different values: $30 \%$, $40 \%, 50 \%, 60 \%, 70 \%$, and $80 \%$, with a temperature is around $30^{\circ} \mathrm{C}$ and the interior doors are left open. 
Table 6. Average radon concentration $\left(\mathrm{Bq}^{-3}\right)$ in hotroom for various relative humidities with $\mathrm{T}=30^{\circ} \mathrm{C}$

\begin{tabular}{|c|c|c|c|c|c|}
\hline Relative Humidity (\%) & ${ }^{222} \mathbf{R n}$ & ${ }^{218} \mathrm{Po}$ & ${ }^{214} \mathrm{~Pb}$ & ${ }^{214} \mathrm{Bi}$ & $\mathbf{F}$ \\
\hline $40 \%$ & 307.14 & 193.99 & 104.68 & 91.09 & 0.35 \\
\hline $50 \%$ & 312.74 & 218.10 & 133.06 & 116.57 & 0.39 \\
\hline $60 \%$ & 319.61 & 222.99 & 136.04 & 119.18 & 0.43 \\
\hline $70 \%$ & 324.57 & 234.49 & 148.76 & 130.55 & 0.46 \\
\hline $80 \%$ & 327.15 & 243.44 & 159.24 & 139.91 & 0.49 \\
\hline
\end{tabular}

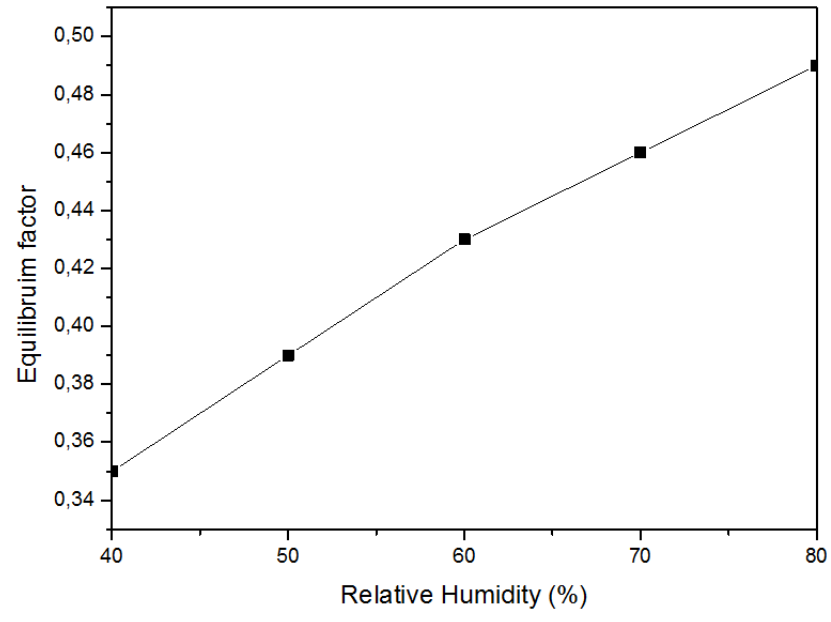

Figure 10. Average equilibrium factor in hotroom for $40 \% \leq R H \leq 80 \%$.

of relative humidity. We observe that the concentration of radon and its descendants gradually increases with increasing relative humidity. Indeed, when humidity increases inside the Hammam, the diffusion coefficient decreases, which reduces the diffusion length of radon and consequently reduces its transfer to areas of low concentration.

Figure 10 shows the evolution of the average equilibrium factor as a function of relative humidity, we see that the equilibrium factor increases as relative humidity increases. This can be interpreted by the attachment of radon descendants to tiny drops of water suspended in the air [7].

In order to have an idea of the effect of relative humidity on the distribution of radon, we present the isoconcentrations of radon at different relative humidity levels $(60 \%$ and $80 \%)$ which are illustrated in Figures 11 and 12. By comparing these figures, we see that the radon concentration increases slightly with relative humidity.

Table 6 represent the average values of the concentration of radon and its descendants inside the hotroom as a function

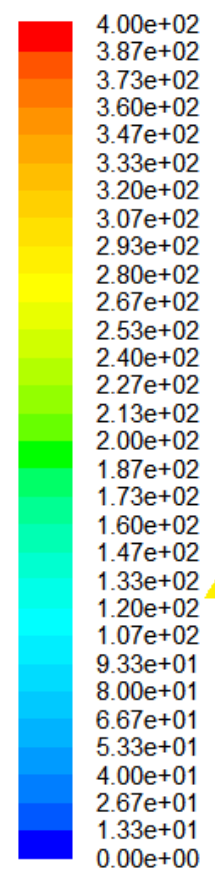

Figure 11. Contours of radon concentration in the Hammam for $\mathrm{RH}=60 \%$. 


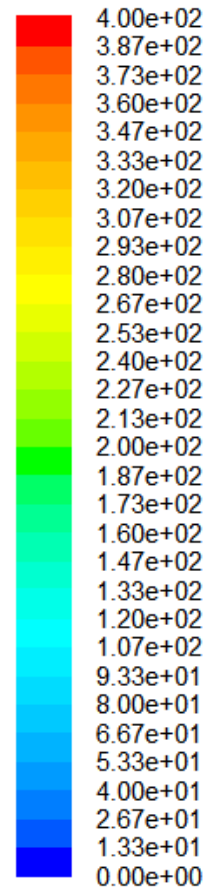

Figure 12. Contours of radon concentration in the Hammam for $R H=80 \%$.

\subsection{Committed Equivalent Doses Due to Radon and Its Decay Products in the Respiratory Tract Inside the Hammam}

The annual committed equivalent doses due to the ${ }^{218} \mathrm{Po}$ and ${ }^{214} \mathrm{Po}$ have been evaluated in the respiratory tract of different age groups inside the Hammam. Data obtained for the adult males, females, Child $10 \mathrm{y}$ and Child $5 \mathrm{y}$ are shown in Tables 7, 8 and 9. It is found that the annual committed equivalent doses due to the ${ }^{214} \mathrm{Po}$ are smaller than those due to ${ }^{218} \mathrm{Po}$ in the extrathoracic ET and thoracic TH regions, this is due to the fact that ${ }^{214} \mathrm{Po}$ has a very short half-life $\left(1.64 \times 10^{-4} \mathrm{~s}\right)$ compared with the exposure time of the tissues.
We remark that the adult male is more exposed than the adult female. This is due to the physiological nature of these adults (breathing rate).

Annual effective doses due to radon progeny from the inhalation of radon decay inside the Hammam by the members of public were evaluated by using the model given here (Equation 11) and the UNSCEAR formula (Equation 12) (Table 10). Data obtained for the average effective dose obtained by using the model given here for different age groups of individuals were found in good agreement with those obtained by using the UNSCEAR model for the general public.

Table 7. Data obtained for annual committed equivalent dose (in $S v y^{-1} h^{-1}$ exposure) due to ${ }^{218}$ Po and ${ }^{214}$ Po in the compartments of the respiratory tract for adult male from the inhalation of air in coldroom.

\begin{tabular}{|c|c|c|c|c|c|c|c|c|}
\hline \multirow{2}{*}{$\begin{array}{l}\text { Respiratory } \\
\text { tract region }\end{array}$} & \multicolumn{4}{|l|}{${ }^{218} \mathrm{Po}$} & \multicolumn{4}{|l|}{${ }^{214} \mathrm{Po}$} \\
\hline & Adult male & Adult female & Child $10 y$ & Child $5 y$ & Adult male & Adult female & Child $10 y$ & Child $5 \mathrm{y}$ \\
\hline $\mathrm{AI}$ & $1.2310^{-8}$ & $8.8110^{-9}$ & $1.6710^{-8}$ & $2.5510^{-8}$ & $3.5210^{-15}$ & $2.5510^{-15}$ & $4.7510^{-15}$ & $7.2210^{-15}$ \\
\hline $\mathrm{bb}$ & $1.7610^{-6}$ & $1.4910^{-6}$ & $1.8510^{-6}$ & $2.0210^{-6}$ & $5.1910^{-13}$ & $4.2210^{-13}$ & $5.1910^{-13}$ & $5.6310^{-13}$ \\
\hline $\mathrm{BB}$ & $5.1110^{-7}$ & $4.7510^{-7}$ & $5.5510^{-7}$ & $6.6910^{-7}$ & $1.4010^{-13}$ & $1.2310^{-13}$ & $1.5810^{-13}$ & $1.8510^{-13}$ \\
\hline $\mathrm{ET}_{1}$ & $5.6310^{-7}$ & $4.5810^{-7}$ & $7.4910^{-7}$ & $1.2310^{-6}$ & $1.5810^{-13}$ & $1.3210^{-13}$ & $2.1110^{-13}$ & $3.6110^{-13}$ \\
\hline $\mathrm{ET}_{2}$ & $2.1110^{-5}$ & $1.6710^{-5}$ & $2.9910^{-5}$ & $5.1110^{-5}$ & $7.6610^{-12}$ & $6.0810^{-12}$ & $1.0510^{-11}$ & $1.8710^{-11}$ \\
\hline
\end{tabular}

Table 8. Data obtained for annual committed equivalent dose (in $S v y^{-1} h^{-1}$ exposure) due to ${ }^{218}$ Po and ${ }^{214}$ Po in the compartments of the respiratory tract for adult male from the inhalation of air in warmroom.

\begin{tabular}{|c|c|c|c|c|c|c|c|c|}
\hline \multirow{2}{*}{$\begin{array}{l}\text { Respiratory } \\
\text { tract region }\end{array}$} & \multicolumn{4}{|l|}{${ }^{218} \mathrm{Po}$} & \multicolumn{4}{|l|}{${ }^{214} \mathrm{Po}$} \\
\hline & Adult male & Adult female & Child $10 \mathrm{y}$ & Child 5 y & Adult male & Adult female & Child $10 y$ & Child 5 y \\
\hline $\mathrm{AI}$ & $1.2610^{-8}$ & $9.0310^{-9}$ & $1.7110^{-8}$ & $2.6210^{-8}$ & $3.6110^{-15}$ & $2.6210^{-15}$ & $4.8710^{-15}$ & $7.4010^{-15}$ \\
\hline $\mathrm{bb}$ & $1.8010^{-6}$ & $1.5310^{-6}$ & $1.8910^{-6}$ & $2.0710^{-6}$ & $5.3310^{-13}$ & $4.3310^{-13}$ & $5.3310^{-13}$ & $5.7810^{-13}$ \\
\hline BB & $5.2410^{-7}$ & $4.8710^{-7}$ & $5.6910^{-7}$ & $6.8610^{-7}$ & $1.4410^{-13}$ & $1.2610^{-13}$ & $1.6210^{-13}$ & $1.8910^{-13}$ \\
\hline $\mathrm{ET}_{1}$ & $5.7810^{-7}$ & $4.6910^{-7}$ & $7.6710^{-7}$ & $1.2610^{-6}$ & $1.6210^{-13}$ & $1.3510^{-13}$ & $2.1610^{-13}$ & $3.7010^{-13}$ \\
\hline $\mathrm{ET}_{2}$ & $2.1610^{-5}$ & $1.7110^{-5}$ & $3.0710^{-5}$ & $5.2410^{-5}$ & $7.8610^{-12}$ & $6.2310^{-12}$ & $1.0810^{-11}$ & $1.9210^{-11}$ \\
\hline
\end{tabular}


Table 9. Data obtained for annual committed equivalent dose (in $S v y^{-1} h^{-1}$ exposure) due to ${ }^{218}$ Po and ${ }^{214}$ Po in the compartments of the respiratory tract for adult male from the inhalation of air in hotroom.

\begin{tabular}{|c|c|c|c|c|c|c|c|c|}
\hline \multirow{2}{*}{$\begin{array}{l}\text { Respiratory } \\
\text { tract region }\end{array}$} & \multicolumn{4}{|l|}{${ }^{218} \mathrm{Po}$} & \multicolumn{4}{|l|}{${ }^{214} \mathrm{Po}$} \\
\hline & Adult male & Adult female & Child $10 y$ & Child 5 y & Adult male & Adult female & Child $10 y$ & Child $5 y$ \\
\hline $\mathrm{AI}$ & $1.3510^{-8}$ & $9.6510^{-9}$ & $1.8310^{-8}$ & $2.8010^{-8}$ & $3.8610^{-15}$ & $2.8010^{-15}$ & $5.2110^{-15}$ & $7.9110^{-15}$ \\
\hline $\mathrm{bb}$ & $1.9310^{-6}$ & $1.6410^{-6}$ & $2.0210^{-6}$ & $2.2210^{-6}$ & $5.6910^{-13}$ & $4.6310^{-13}$ & $5.6910^{-13}$ & $6.1810^{-13}$ \\
\hline BB & $5.6010^{-7}$ & $5.2110^{-7}$ & $6.0810^{-7}$ & $7.3410^{-7}$ & $1.5410^{-13}$ & $1.3510^{-13}$ & $1.7310^{-13}$ & $2.0210^{-13}$ \\
\hline $\mathrm{ET}_{1}$ & $6.1810^{-7}$ & $5.0210^{-7}$ & $8.2010^{-7}$ & $1.3510^{-6}$ & $1.7310^{-13}$ & $1.4410^{-13}$ & $2.3110^{-13}$ & $3.9510^{-13}$ \\
\hline $\mathrm{ET}_{2}$ & $2.3110^{-5}$ & $1.8310^{-5}$ & $3.2810^{-5}$ & $5.6010^{-5}$ & $8.4010^{-12}$ & $6.6610^{-12}$ & $1.1510^{-11}$ & $2.0510^{-11}$ \\
\hline
\end{tabular}

Table 10. Data obtained for the effective dose (in $S v y^{-1} h^{-1}$ of exposure) due to ${ }^{218} P o$ and ${ }^{214}$ Po radon decay products from the inhalation of air in the hammam by different age groups by using the method here and the UNSCEAR (2000) dose conversion coefficient.

\begin{tabular}{|c|c|c|c|c|c|c|}
\hline Space & ICRP & Adult male & Adult female & Child $10 y$ & Child $5 \mathrm{y}$ & Average \\
\hline Coldroom & $1.0010^{-6}$ & $7.9310^{-7}$ & $7.0410^{-7}$ & $1.0510^{-6}$ & $1.5810^{-6}$ & $1.0310^{-6}$ \\
\hline Warmroom & $1.0310^{-6}$ & $8.1310^{-7}$ & $7.2210^{-7}$ & $1.0810^{-6}$ & $1.6210^{-6}$ & $1.0610^{-6}$ \\
\hline Hotroom & $1.1010^{-6}$ & $8.6910^{-7}$ & $7.7210^{-7}$ & $1.1510^{-6}$ & $1.7310^{-6}$ & $1.1310^{-6}$ \\
\hline
\end{tabular}

\section{Conclusion}

We have studied numerically using CFD simulation the effects of ventilation, temperature, and relative humidity on the concentration and distribution of radon and its descendants inside a traditional hammam. The results showed that the concentration of radon decreases while increasing the rate of ventilation, as well as, when the temperature increases, however, it increases with increasing relative humidity. As well as, the Annual committed equivalent doses due to ${ }^{218} \mathrm{Po}$ and ${ }^{214} \mathrm{Po}$ were determined in the respiratory tract of adult members of the public from the inhalation of air inside the hammam. From this, we see that the CFD simulation a good tool to assess the doses of radon to individuals from inhaling radon offspring in indoor air.

\section{References}

[1] United Nations Scientific Committee on the Effects of Atomic Radiation (UNSCEAR), 2000. Sources and Effects of Ionising Radiation, vol. I. Annex B. United Nations, New York.

[2] Visnuprasad, A. K., Reby, R. K. E., Jojo, P. J., Sahoo, B. K. (2019) Comparison of results from indoor radon measurements using active and passive methods with those from mathematical modeling. Radiation and Environmental Biophysics 58: 345-352.

[3] García-Tobar, J. (2020) Study of Radon Propagation in A Dwelling Using the CFD Modelling Capabilities of CONTAM, To Physics Journal 5: 2581-7396.

[4] Rabi, R., Oufni, L. (2017) A theoretical investigation of the distribution of indoor radon concentrations. Indian J. Phys. 91: 471-479.

[5] Lima Flores, A., Palomino-Merino, R., Castaño, V. M.,
Espinosa, G. (2020) Analysis of Indoor Radon Distribution Within a Room By Means of Computational Fluid Dynamics (CFD) Simulation. J. Nucl. Phys. Mat. Sci. Rad. A. 7: 89-95.

[6] Wang, X., Feng, G., Liu, Q., Wu, B., Hu, Y. (2020) CFD based simulation of indoor radon distribution from the use of different brands of decorative glazed tiles made in China. Radiation Effects and Defects in Solids.

[7] Rabi, R., Oufni, L. (2017) Study of radon dispersion in typical dwelling using CFD modeling combined with passive-active measurements. Radiat. Phys. Chem. 139: 40-48.

[8] Agarwal, T. K., Joshi, M., Sahoo, B. K., Kanse, S. D., Sapra B. K. (2016) Effect of ${ }^{220} \mathrm{Rn}$ gas concentration distribution on its transmission from a delay chamber: evolving a CFD-based uniformity index. Radiat. Prot. Dosimetry 168: 546-552.

[9] Agarwal, T. K., Sahoo, B. K., Gaware, J. J., Joshi, M., Sapra, B. K. (2014) CFD based simulation of thoron $\left({ }^{220} \mathrm{Rn}\right)$ concentration in a delay chamber for mitigation application. $\mathrm{J}$. Environ. Radio. 136: 16-21.

[10] Rabi, R., Oufni, L., Amrane, M. (2017) Modeling of indoor ${ }^{222} \mathrm{Rn}$ distribution in ventilated room and resulting radiation doses measured in the respiratory tract. Journal of Radiation Research and Applied Sciences 10: 273-282.

[11] Lide, D. (2004) CRC Handbook of chemistery and physics. Florida: CRC press.

[12] International Commission on Radiological Protection, Proceedings of the Third International Symposium on the System of Radiological Protection (2016) Annals of the ICRP 45: $1 \mathrm{~S}$.

[13] Singh, K., Singh, M., Singh, S., Sahota, H. S., Papp, Z. (2005) Variation of radon $\left({ }^{222} \mathrm{Rn}\right)$ progeny concentrations in outdoor air as a function of time, temperature and relative humidity. J. Environ. Radioact. 39: 213-217.

[14] Singh, M., Singh, K., Singh, S., Papp, Z. (2008) Variation of indoor radon progeny concentration and its role in dose assessment. J. Environ. Radioact. 99: 539-545. 